\title{
Human papillomavirus and oral manifestations in a patient with HIV: A case report and literature review
}

\author{
KARTHIK RAJARAMMOHAN, RAVIKUMAR PETHAGOUNDER THANGAVELU, \\ SARAMMA MATHEW FENN and ARUN VIGGNESS
}

\begin{abstract}
Department of Oral Medicine and Radiology, Vinayaka Mission's Sankarachariyar Dental College, Vinayaka Mission's Research Foundation (Deemed to be University), Ariyanoor, Tamil Nadu 636308, India
\end{abstract}

Received May 12, 2021; Accepted September 3, 2021

DOI: $10.3892 /$ wasj.2021.127

\begin{abstract}
Oral lesions in patients with human immunodeficiency virus (HIV) include acute pseudomembranous candidiasis, pigmentation, HIV-associated periodontitis and oral hairy leukoplakia. Papillomas can also occur in patients with HIV. Papillomas are benign exophytic growths that can occur anywhere in the human body. The surface of such papillomas have characteristic numerous finger-like projections and usually appear necrotic due to thrombosed capillaries. The present study describes the case of a 72-year-old male patient with HIV with various oral lesions. The present study also discusses the incidence and presentation of papillomas and their association with HIV, and emphasizes that, if papillomas are present on the skin or oral mucosa, they can be used as a clinical marker for HIV, indicating an underlying immunosuppressive state. Thus, caution is required when a skin papilloma is clinically detected in a patient.
\end{abstract}

\section{Introduction}

Oral lesions encountered in patients with human immunodeficiency virus (HIV) vary from acute pseudomembranous candidiasis, oral hairy leukoplakia and pigmentation of the oral mucosa. Recently, papillomas have also been reported, which serve as a clinical marker for patients with HIV. Bzhalava et al (1) stated that the human papillomaviruses (HPVs) are classified into the $\alpha, \beta$ and $\gamma$ genus. They belong to the family Papillomaviridae, a family of ancient ubiquitous viruses, with $>200$ types of species-specific viruses and containing $~ 16$ genera based on the International Committee

Correspondence to: Dr Karthik Rajarammohan, Department of Oral Medicine and Radiology, Vinayaka Mission's Sankarachariyar Dental College, Vinayaka Mission's Research Foundation (Deemed to be University), NH-47, Sankari Main Road, Ariyanoor, Salem, Tamil Nadu 636308, India

E-mail: drkarthik@vmsdc.edu.in

Key words: acute pseudomembranous candidiasis, human immunodeficiency virus, oral pigmentation, papilloma on the Taxonomy of Viruses (ICTV) (2). Papillomas can occur anywhere in the human body. Cubie (3) described the various diseases associated with HPV infection. One must be cautious whenever a skin papilloma is clinically detected in a patient. The presence of papillomas on the skin or oral mucosa may be a clinical marker for HIV and may indicate an underlying immunocompromised state, that warrants a thorough investigation. The present study describes the case of a 72-year-old male patient with HIV who presented with oral lesions. In addition, a discussion and summary of papillomas and their association with HIV is also presented.

\section{Case report}

Ethics approval was obtained from the Sankarachariyar Dental College, Vinayaka Missions Research Foundation (Deemed to be University), Tamil Nadu, India. Patient consent was obtained for publication of his clinical images, concealing his identity.

A 72-year-old male presented to the Department of Oral Medicine and Radiology, Vinayaka Mission's Sankarachariyar Dental College, Vinayaka Mission's Research Foundation (Deemed to be University), Ariyanoor, India for a routine dental check-up. An analysis of his personal history revealed that he was a chronic beedi smoker and smokes $\sim 1$ packet per day for 15 years. Upon the further investigation into his medical history, it was revealed that he had sexual contacts with multiple partners. His past medical history revealed that he suffered from a chronic cough for $>2$ months, with a rise in temperature in the evenings and weight loss. A general examination revealed he was poorly built and nourished. An extraoral examination revealed a palpable right submandibular lymph node $\sim 1 \mathrm{~cm}$ in diameter, mobile, firm in consistency and tender on palpation. An extraoral examination revealed an exophytic growth on the skin near his right forehead region. The surface of the growth revealed numerous fine finger-like projections, and the growth appeared pedunculated (Fig. 1). An intraoral examination revealed severe black coal tar nicotine stains on all his teeth. He had multiple missing teeth (teeth nos. 11, 12, 13, 21, $26,27,31,32,35,36,37,41,42,43,44,45,46$ and 47) (4). The buccal cusp of tooth no. 25 was sharp due to severe attrition. Numerous discrete 'cauliflower-like' growths were observed 


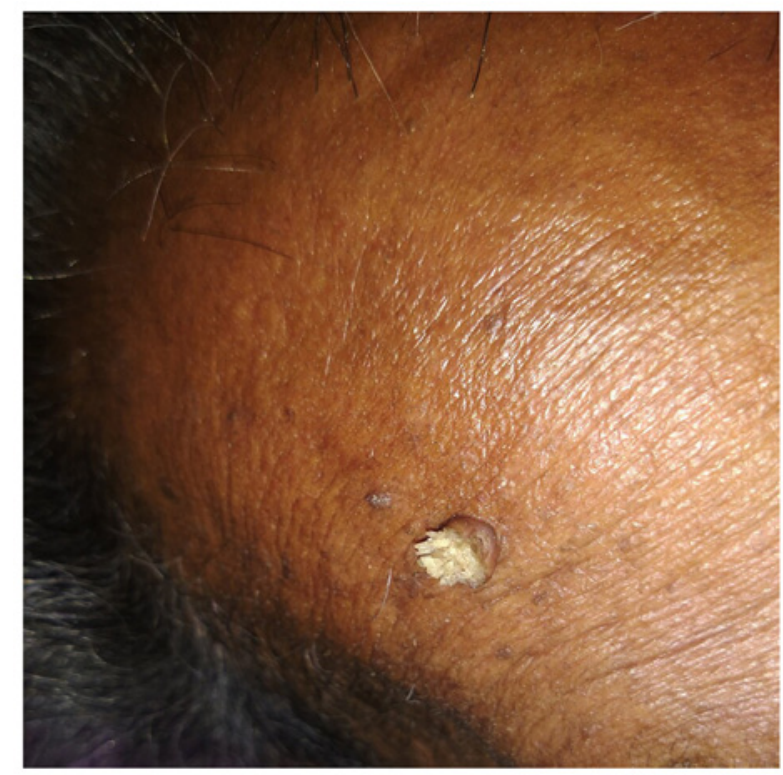

Figure 1. Cutaneous papilloma on the skin of the forehead.

in the middle portion of the hard palate. They were sessile, non-pedunculated, firm in consistency and non-tender (Fig. 2). Discrete curdy precipitates were present near the junction of the posterior section of the hard and soft palate, which were scrapable, leaving behind a raw erythematous area, suggestive of acute pseudomembranous candidiasis (Fig. 3). The examination of the right buccal mucosa revealed discrete areas of greyish pigmentation (Fig. 4A). The examination of the left buccal mucosa revealed a growth along the occlusal plane measuring $\sim 0.5 \mathrm{~cm}$ in diameter, which was the same colour as that on the adjacent mucosa, and was non-pedunculated, sessile, non-tender on palpation and firm in consistency (Fig. 4B). The examination of the right lateral border of the tongue revealed numerous vertical white corrugated appearances which were non-scrapable, suggestive of oral hairy leukoplakia (Fig. 5).

Taking into consideration the patient's history and clinical findings, a provisional diagnosis was made of a cutaneous wart on the skin of forehead, multiple papillomatous warts on the hard palate, and pseudomembranous candidiasis near the junction of hard and soft palate. Oral hairy leukoplakia was also diagnosed on the right lateral border of the tongue, and a diagnosis of an irritation fibroma on the left buccal mucosa was made. The laboratory diagnosis of the CD4 count revealed 192 cells $/ \mathrm{mm}^{3}$ of blood. The results of ELISA for HIV were positive. The serum test results for HPV DNA antibodies were also positive. The 23-HPV PCR test kit revealed reactivity to the HPV4 subtype. The patient was then referred to the Y.R. Gaitonde Centre for AIDS Research and Education (YRGCARE), Chennai, India.

\section{Discussion}

HIV infection is characterized by progressive immunosuppression due to low absolute CD4 counts and a disrupted cytokine network which manifests the clinical consequences of HIV infection, ranging from an acute syndrome associated

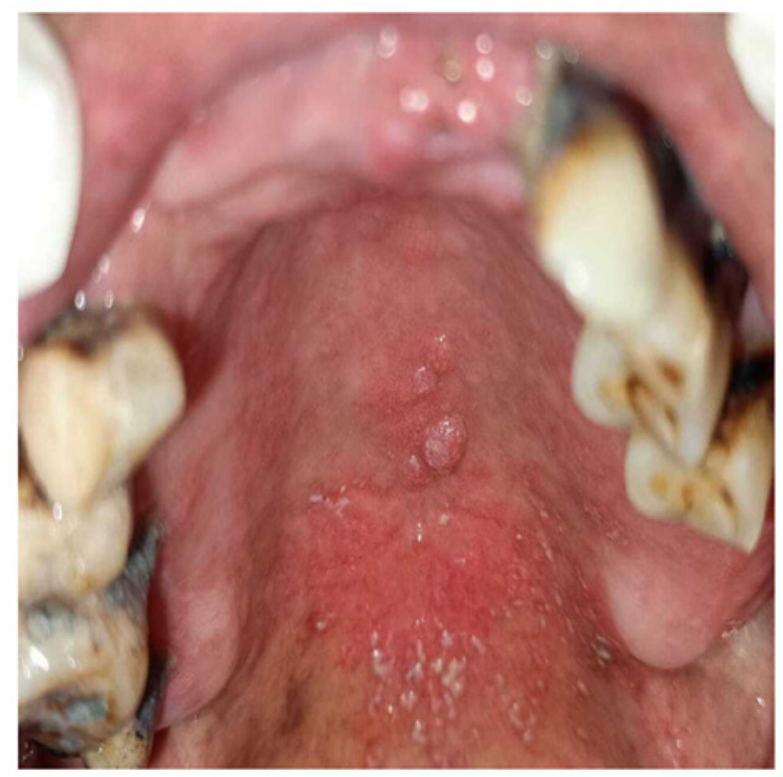

Figure 2. Multiple papilloma on the hard palate.

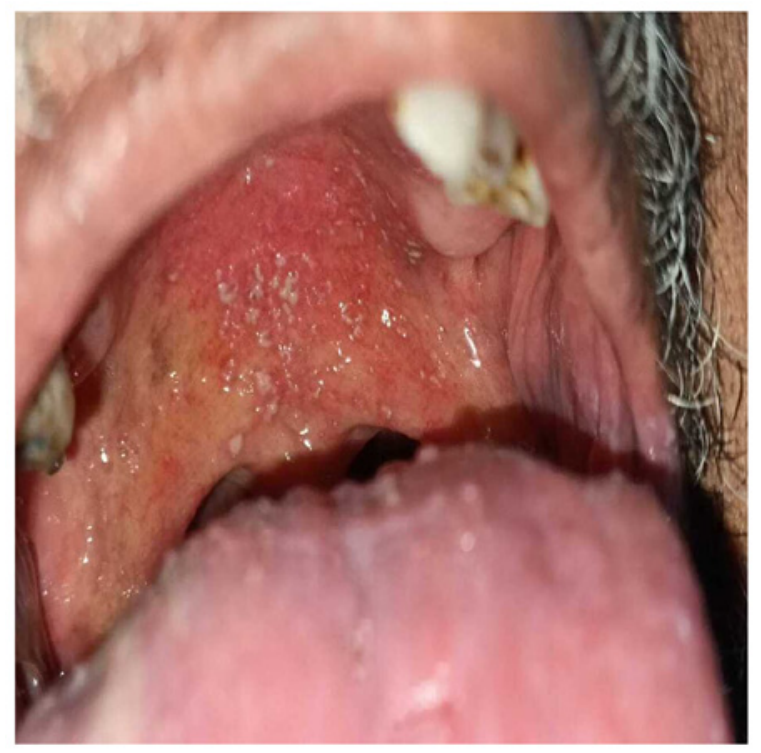

Figure 3. Acute pseudomembranous candidiasis on the junction of the hard and soft palate.

with primary infection to prolonged asymptomatic infection, to advanced clinical manifestations.

The oral cavity is a mirror that reflects systemic illness, which unravels hidden diseases in the human body. In the present study, only following the thorough examination of his oral cavity, the patient admitted that he had sexual contact with multiple partners. Hence, a thorough history of the patient and clinical examination is essential. Cutaneous HPVs belong to the $\beta$ genus with a few members in the $\gamma$, mu and nu genera. The various subtypes of HPV have been presented in a previous study (1). HPV types 5 and 8 cause squamous cell carcinoma on exposed skin; HPV types 2, 6, 7, 11, 16, 18, 32 and 57 cause oral papillomas; HPV type 6 causes Buschke-Lowenstein tumours; HPV types 6 and 11 cause laryngeal papillomas; HPV types 13 and 32 cause focal epithelial hyperplasia 

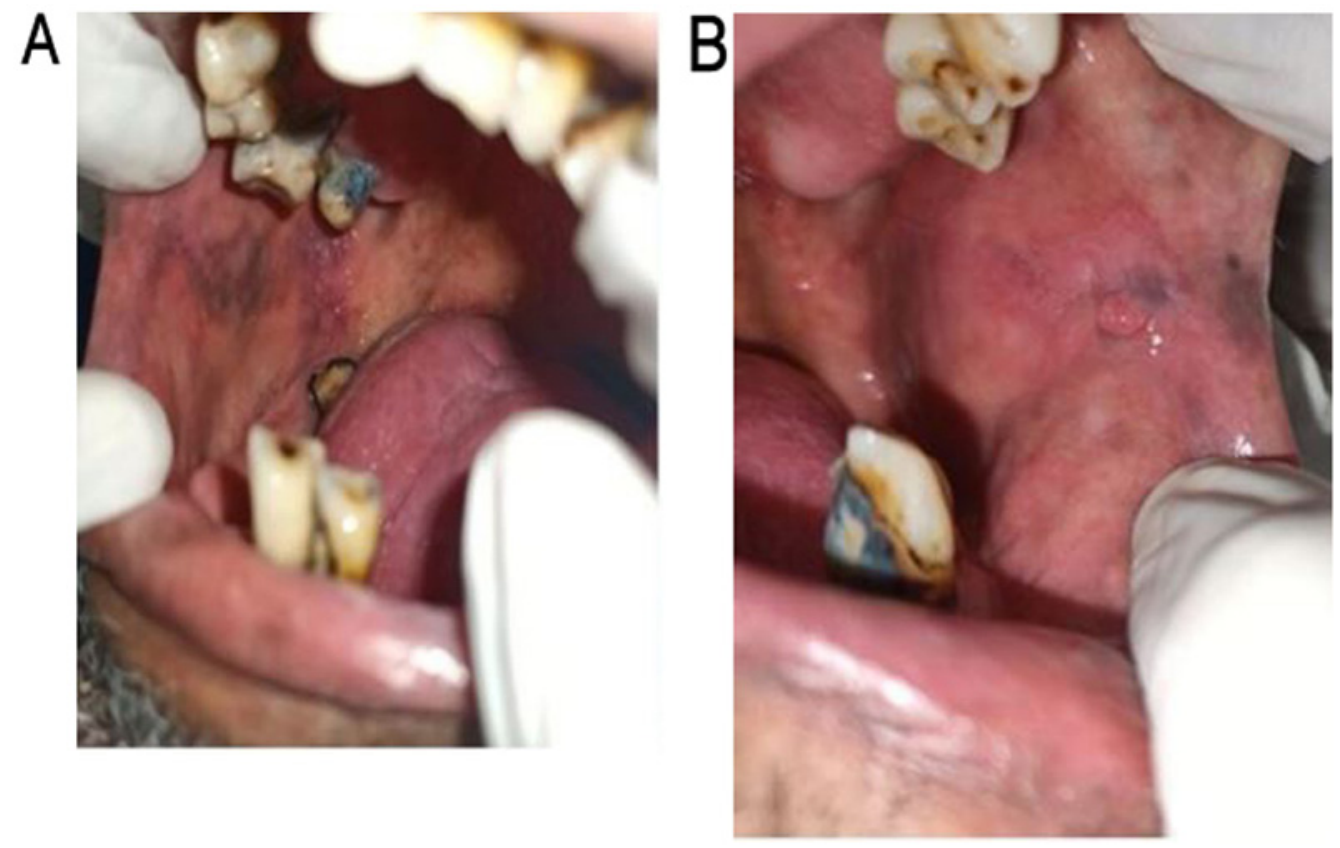

Figure 4. (A) Examination of the pigmentation of the right buccal mucosa. (B) Examination of the left buccal mucosa, revealing an irritation fibroma.

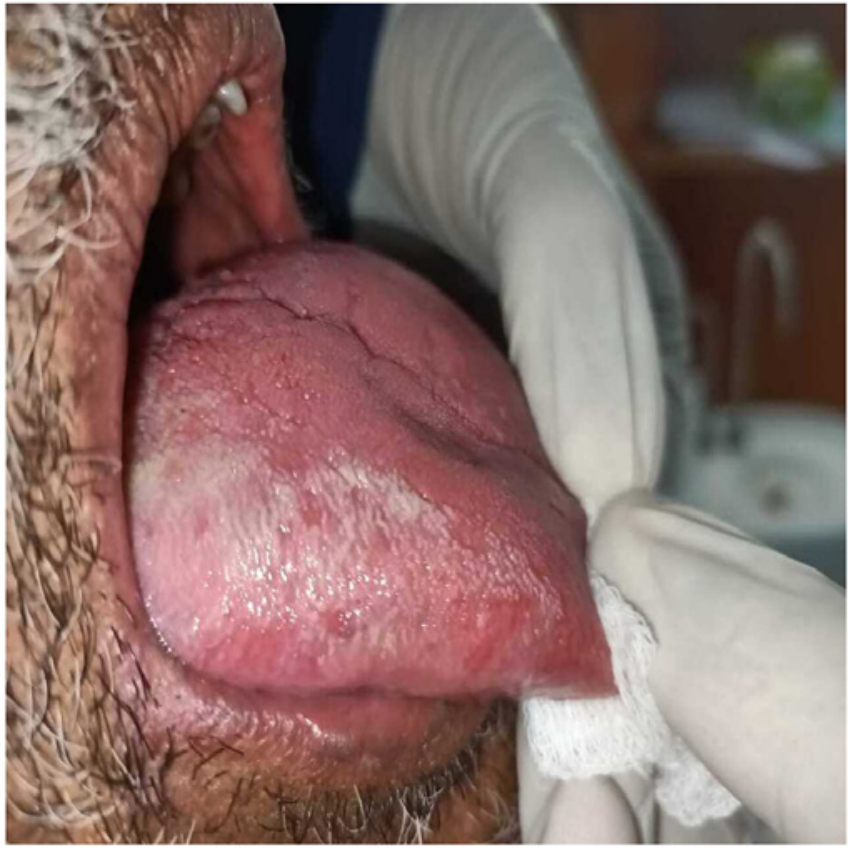

Figure 5. Examination of the right dorsum and lateral border of the tongue, revealing hairy leukoplakia.

(Heck's disease); HPV types 3 and 10 cause epidermodysplasia verruciformis; and HPV types 16 and 55 cause Bowenoid papulosis. Such cutaneous HPV warts are usually observed in immunocompromised patients with acquired immune deficiency syndrome (AIDS) due to underlying HIV, and in patients who have undergone renal transplants. The regrowth of lesions following treatment occurs frequently due to the persistence of the virus in the skin surrounding the original wart. Various research case reports on the occurrence of papillomas in various regions and complications are presented in Table I (5-18).
Papillomas are benign outgrowths with finger-like projections on the surface caused by HPV. This virus selectively infects the epithelium of the skin and mucous membranes. HPVs are non-enveloped double-stranded DNA viruses, measuring $~ 50-55 \mathrm{~nm}$ in diameter, with icosahedral capsids composed of 72 capsomeres and a genome of $\sim 7,900 \mathrm{bp}$. The L1 gene codes for the major capsid protein and comprises up to $80 \%$ of the virion mass. Common warts, also termed verruca vulgaris, occur on the hands as flesh-coloured to brown, exophytic, hyperkeratotic papules. Filiform warts are most commonly observed on the face, neck and skin folds, and present as papillomatous lesions on a narrow base. Flat warts are only slightly elevated and have a velvety surface, with a propensity for the face, arms and legs, and are often spread by shaving. Plantar warts (verruca plantaris) are painful and cause surface calluses due to thrombosed capillaries. Anogenital warts occur in the external genitalia and penile skin. The main complications of warts include itching and occasional bleeding. In rare instances, secondary infections can occur due to bacteria or fungi. The incubation period for HPV is usually is 3-4 months and ranges from 1 month to 2 years (19).

HPV infects the squamous epithelium and the replication of the virus usually begins with the infection of the basal cells. Following cellular differentiation, HPV-DNA is transcribed and released when keratinocytes are shed. Residual DNA is usually present in recurrent cases following surgical excision (19). In the case presented herein, since the patient had a history of sexual contact with multiple partners, it was also possible that he came into contact with a papilloma of another individual, which also can spread by sexual contact with an infected partner. He also had lesions of scrapable curdy white deposits near the junction of the posterior aspect of the hard and soft palate, confirming the presence of HIV-induced acute pseudomembranous oral candidiasis. The pigmentation on the buccal mucosa may have been due to the HIV infection that 
Table I. Reported cases of papilloma in the literature.

\begin{tabular}{|c|c|c|c|}
\hline Authors/(Refs.) & $\begin{array}{c}\text { Year of } \\
\text { publication }\end{array}$ & $\begin{array}{l}\text { Age (years)/ } \\
\text { no. of patients }\end{array}$ & Location/notes \\
\hline Orenuga et al (5) & 2018 & $\begin{array}{l}\text { 5-Year-old- } \\
\text { peadiatric } \\
\text { patient }\end{array}$ & $\begin{array}{l}\text { Papilloma is a benign proliferating lesion, painless, with a slow } \\
\text { growth, sometimes mimicking exophytic carcinoma on the } \\
\text { hard palate }\end{array}$ \\
\hline Liu and Huo (6) & 2018 & $\begin{array}{l}\text { 34-Year-old } \\
\text { patient }\end{array}$ & $\begin{array}{l}\text { Papilloma in the larynx was accidentally discovered by an } \\
\text { endoscopy, during surgery for a tonsillar cyst }\end{array}$ \\
\hline Li et al (7) & 2020 & $\begin{array}{l}188 \text { Intraductal } \\
\text { papillomas } \\
\text { diagnosed by core } \\
\text { needle biopsy }\end{array}$ & $\begin{array}{l}\text { Intraductal papillomas (IDPs) diagnosed on core needle biopsy } \\
(\mathrm{CNB}) \text { remain controversial }\end{array}$ \\
\hline Yildırım et al (8) & 2015 & $\begin{array}{l}\text { 40-Year-old male } \\
\text { patient }\end{array}$ & $\begin{array}{l}\text { A papillomatous lesion at the posterolateral wall of the distal } \\
1 / 3 \text { of the trachea, causing } \sim 80 \% \text { obstruction at the lumen. The } \\
\text { lesions were extracted under general anaesthesia via } \\
\text { endobronchial therapy by rigid bronchoscopy (mechanical } \\
\text { debridement and cryotherapy) }\end{array}$ \\
\hline Goel et al (9) & 2014 & $\begin{array}{l}\text { 14-Year-old male } \\
\text { patient }\end{array}$ & $\begin{array}{l}\text { Papilloma presenting as an exophytic mass on the hard palate } \\
\text { for a period of } 7 \text { months, mimicking as a carcinoma }\end{array}$ \\
\hline van der Putten et al (10) & 2013 & $\begin{array}{l}\text { 74-Year-old } \\
\text { Caucasian female }\end{array}$ & $\begin{array}{l}\text { Schneiderian papilloma of the temporal bone associated with } \\
\text { conduction hearing loss. A positive human papilloma virus } \\
\text { status is a common feature and prognostic factor of sinonasal } \\
\text { Schneiderian papilloma, but an infrequent finding in temporal } \\
\text { bone disease. Stingent follow-up by otoscopy, nasal endoscopy } \\
\text { and imaging is essential }\end{array}$ \\
\hline Burduk et al (11) & 2013 & NA & $\begin{array}{l}\text { Papilloma of the lacrimal sac, resulting in frequent epiphora } \\
\text { and recurrent dacrocystitis }\end{array}$ \\
\hline D'Souza et al (12) & 2007 & $\begin{array}{l}\text { Hospital-based, } \\
\text { case-control study } \\
\text { of } 100 \text { patients } \\
\text { newly diagnosed } \\
\text { with oropharyngeal } \\
\text { cancer and } \\
200 \text { control patients } \\
\text { without cancer }\end{array}$ & $\begin{array}{l}\text { Oral HPV infection is strongly associated with oropharyngeal } \\
\text { cancer among subjects with or without the established risk } \\
\text { factors of tobacco and alcohol use }\end{array}$ \\
\hline Karpinski and Miller (13) & 2002 & $\begin{array}{l}\text { 26-Year-old } \\
\text { patient }\end{array}$ & $\begin{array}{l}\text { Papillomas occurring bilaterally in the cornea and were treated } \\
\text { with } 25 \mathrm{mg} 5 \text {-fluorouracil in a course duration of } 17 \text { weeks }\end{array}$ \\
\hline Mirza et al (14) & 2000 & NA & Papilloma occurring in the submandibular gland \\
\hline Bawa et al (15) & 1995 & NA & $\begin{array}{l}\text { Papilloma in the nasal septum occurring as a rare histologically } \\
\text { distinct variant of papillomas; cylindrical papillomas of the } \\
\text { sinonasal tract behave clinically as inverted papillomas }\end{array}$ \\
\hline Gilain et al (16) & 1993 & $\begin{array}{l}\text { 51-year-old } \\
\text { male }\end{array}$ & $\begin{array}{l}\text { Papilloma occurring in the nose and paranasal sinus. Unilateral } \\
\text { nasal obstruction is the most common clinical sign }\end{array}$ \\
\hline Basheda et al (17) & 1991 & $\begin{array}{l}\text { 74-Year-old } \\
\text { male }\end{array}$ & $\begin{array}{l}\text { Papilloma lined by columnar epithelium centrally located in } \\
\text { the airways, causing atelectasis }\end{array}$ \\
\hline Aoki et al (18) & 1976 & $\begin{array}{l}\text { 31-Year-old } \\
\text { female }\end{array}$ & $\begin{array}{l}\text { Papillomas of the gallbladder may be associated with } \\
\text { cholesterolosis and malignant degeneration, but no stones. } \\
\text { Cholecystectomy is the treatment of choice }\end{array}$ \\
\hline
\end{tabular}

NA, not available. 
Table II. Medical management of papillomas or warts.

By the physician

Cryotherapy with liquid nitrogen using a cryoprobe

$10-25 \%$ Podophyllin resin -weekly for a duration of up to 4 weeks

$80-90 \%$ of Trichloroacetic acid

Intra-lesionally administered interferon

Surgical excision using a laser

Intralesional 5-fluorouracil; $25 \mathrm{mg}$ administered over a period of 17 weeks

By the patient

Podofilox ( $0.5 \%$ solution or gel) twice daily for 3 days followed by 4 days without therapy. This cycle is repeated four times Imiquimod (5\% cream) -3 times per week for $\sim 16$ weeks.

Topical 5-fluorouracil application

Adapted from Harrisons Manual of Medicine, 18th edition (26).

Table III. Initial antiretroviral therapy regimen.

Initial antiretroviral treatment regimen

Single-tablet formulation

Abacavir/lamivudine/dolutegravir (ABC/3TC/DTG; Triumeq)

Tenofovir alafenamide/emtricitabine/bictegravir (TAF $25 \mathrm{mg} / \mathrm{FTC} / \mathrm{BIC}$; Bictarvy)

$\mathrm{CrCl}>50 \mathrm{Ml} / \mathrm{min}$

$\mathrm{CrCl}>30 \mathrm{Ml} / \mathrm{min}$

Multi-tablet regimen with once daily dosing

Tenofovir alafenamide/emtricitabine and dolutegravir (TAF 25 mg FTC

$\mathrm{CrCl}>30 \mathrm{Ml} / \mathrm{min}$ and DTG; Descovy and Tivicay)

Tenofovir alafenamide/emtricitabine and raltegravir (TAF 25 mg/FTC

$\mathrm{CrCl}>30 \mathrm{Ml} / \mathrm{min}$ and RAL HD; Descovy and Isentress HD)

$\mathrm{CrCl}$, creatinine clearance.

had destroyed the adrenal cortical layer of the adrenal gland, resulting in Addison's disease. The irritation fibroma on his left buccal mucosa was probably due to the irritation by the sharp (due to attrition) buccal cusp of the left maxillary second molar. The loss of multiple teeth was due to HIV-induced periodontitis, which was aggravated by a smoking form of tobacco which favours collagenolysis, resulting in periodontal ligament destruction and hence causing tooth mobility and the avulsion of affected teeth.

A colposcope is a valuable diagnostic tool which can be used to visualise cutaneous and oral HPV lesions. The most sensitive and specific tool is the use of polymerase chain reaction to identify specific subtypes or to detect HPV-DNA in serum. Antibodies to E-7 region proteins are detected in patients with HPV infection (19).

Gordjani et al (20) and Ruzicki et al (21) stated that obstructive papillomas occur in the larynx and hypopharynx region in Gorlin-Goltz syndrome. HPV-DNA can be accessed by PCR and fluorescence in situ hybridisation (FISH) with signal amplification (22). Such warts caused by HPV result in a diagnostic dilemma for dentists. Hoffmann and Tribius (23) stated that p16INK4A should be evaluated as a surrogate marker for HPV-induced carcinoma of the tonsillar region. The treatment of warts depends on factors, such as the location of the wart, the extent, the age of the patient, the immunological status and the patients desire for therapy. The treatment modalities for papilloma are presented in Table II.

$\mathrm{CO} 2$ laser ablation was suggested for patients with respiratory papillomas by Dedo and $\mathrm{Yu}(24)$. The antiretroviral therapy (ART) regimen is initiated once the patient is diagnosed with HIV. The initial ART regimen may be a single tablet regimen or a two-drug regimen (25). Initial ART should be initiated only after performing the creatinine clearance test, if the creatinine clearance value is $>50 \mathrm{Ml} / \mathrm{min}$. A single-tablet formulation containing the drugs abacavir, lamivudine and dolutregavir is prescribed. Antacids can be prescribed either $2 \mathrm{~h}$ prior or $6 \mathrm{~h}$ following the intake of the antiretroviral drug. If the creatinine clearance value is $>30 \mathrm{Ml} / \mathrm{min}$, a single-tablet formulation containing tenofovir alafenamide/emtricitabine/bictegravir or a multi-tablet once daily dosage consisting of either tenofovir alafenamide/emtricitabine and raltegravir (two doses of $600 \mathrm{mg}$ raltegravir) is advocated (25) (Table III).

Oral lesions serve as early markers in the diagnosis of HIV infection, as the oral cavity is a mirror that unravels and also reflects underlying systemic diseases. Dentists need to be aware of the oral manifestations of HIV infection, thus enabling the early identification of HIV and the timely initiation of therapy. A careful evaluation of oral lesions may not only help in the 
diagnosis of HIV, but may also aids in monitoring the disease progression. The patient in the present study was diagnosed with acquired HIV infection based on the clinical findings of acute pseudomembranous candidiasis, multiple papillomas on the hard palate, cutaneous warts, intraoral pigmentation, and oral hairy leukoplakia on the right lateral border of the tongue.

\section{Acknowledgements}

Not applicable.

\section{Funding}

No funding was received.

\section{Availability of data and materials}

The datasets used and/or analysed during the current study are available from the corresponding author on reasonable request.

\section{Authors' contributions}

KR was involved in the writing of the manuscript, and examined and collected patient data. RPT was involved in the literature search and collection. SMF was involved in the conceptualization and design of the study. AV was involved in the collection of the patient data and images. KR and RPT confirm the authenticity of all the raw data. All authors have read and approved the final manuscript.

\section{Ethics approval and consent to participate}

Ethics approval was obtained from the Sankarachariyar Dental College, Vinayaka Missions Research Foundation (Deemed to be University), Tamil Nadu, India. Written consent was obtained from the patient.

\section{Patient consent for publication}

Patient written consent was obtained for publication of his clinical images, concealing his identity.

\section{Competing interests}

The authors declare that they have not competing interests.

\section{References}

1. Bzhalava D, Eklund C and Dillner J: International standardization and classification of human papillomavirus types. Virology 476: 341-344, 2015.

2. Van Doorslaer K, Chen Z, Bernard HU, Chan PKS, DeSalle R, Dillner J, Forslund O, Haga T, McBride AA, Villa LL, et al; Ictv Report Consortium: ICTV Virus Taxonomy Profile: Papillomaviridae. J Gen Virol 99: 989-990, 2018.

3. Cubie HA: Diseases associated with human papillomavirus infection. Virology 445: 21-34, 2013.

4. Keiser-Nielsen S: Federation Dentaire Internationale. Two-Digit System of designating teeth. Dent Pract (Ewell) 3: 6, passim, 1971.
5. Orenuga OO, Oluwo A, Oluwakuyide RT and Olawuyi AB: Recurrent oral squamous papilloma in a pediatric patient: Case report and review of the literature. Niger J Clin Pract 21: 1674-1677, 2018.

6. Liu Q and Huo H: Concomitant tonsillar cyst and papilloma in larynx: A case report. Medicine (Baltimore) 97: e11280, 2018.

7. Li X, Aho M, Newell MS, Clifford K, Patel JG, Jou S and Cohen MA: Papilloma diagnosed on core biopsies has a low upgrade rate. Clin Imaging 60: 67-74, 2020.

8. Yıldırım F, Türk M, Demircan S, Akyürek N and Yurdakul AS: Tracheal Papilloma Treated with Cryotherapy and Interferon- $\alpha$ : A Case Report and Review of the Literature. Case Rep Pulmonol 2015: 356796, 2015.

9. Goel S, Gupta H and Makhijani B: Human papilloma virus: A diagnostic dilemma for dentist. J Cancer Res Ther 10: 778-780, 2014.

10. van der Putten L, Bloemena E, Merkus P and Hensen EF: Schneiderian papilloma of the temporal bone. BMJ Case Rep 2013 (dec05 1): bcr2013201219, 2013.

11. Burduk PK, Seredyka-Burduk M, Kaźmierczak W, Dalke K and Marszałek A: Papilloma of the lacrimal sac. Otolaryngol Pol 67: 52-56, 2013 (In Polish).

12. D'Souza G, Kreimer AR, Viscidi R, Pawlita M, Fakhry C, Koch WM, Westra WH and Gillison ML: Case-control study of human papillomavirus and oropharyngeal cancer. N Engl J Med 356: 1944-1956, 2007.

13. Karpinski LG and Miller CL: Fluorouracil as a treatment for corneal papilloma in a Malayan tapir. Vet Ophthalmol 5: 241-243, 2002.

14. Mirza S, Dutt SN, Irving RM and Jones EL: Intraductal papilloma of the submandibular gland. J Laryngol Otol 114: 481-483, 2000.

15. Bawa R, Allen GC and Ramadan HH: Cylindrical cell papilloma of the nasal septum. Ear Nose Throat J 74: 179-181, 1995.

16. Gilain L, Favre M, Planquart X, abd el Samad I, Le Lièvre G and Peynegre R: Human papillomavirus and nasosinusal inverted papilloma. Ann Otolaryngol Chir Cervicofac 110: 321-325, 1993 (In French).

17. Basheda S, Gephardt GN and Stoller JK: Columnar papilloma of the bronchus. Case report and literature review. Am Rev Respir Dis 144: 1400-1402, 1991.

18. Aoki Y, Okamura T, Kurimoto $\mathrm{H}$ and Taniguchi K: Papilloma of the gallbladder. Am J Surg 131: 614-617, 1976.

19. Abreu AL, Souza RP, Gimenes F and Consolaro ME: A review of methods for detect human Papillomavirus infection. Virol J 9: $262,2012$.

20. Gordjani N, Herdeg S, Ross UH, Grimme H, Kleinschmidt M and Brandis M: Focal dermal hypoplasia (Goltz-Gorlin syndrome) associated with obstructive papillomatosis of the larynx and hypopharynx. Eur J Dermatol 9: 618-620, 1999.

21. Ruzicki J, Nair GS, Wang A, Farmer J and Strube YNJ: Papillomas in Goltz syndrome: Case report, anaesthetic considerations, and review of the literature. Can J Ophthalmol 54: e227-e230, 2019.

22. Acay R, Rezende N, Fontes A, Aburad A, Nunes F and Sousa S: Human papillomavirus as a risk factor in oral carcinogenesis: A study using in situ hybridization with signal amplification. Oral Microbiol Immunol 23: 271-274, 2008.

23. Hoffmann M and Tribius S: HPV and Oropharyngeal Cancer in the Eighth Edition of the TNM Classification: Pitfalls in Practice. Transl Oncol 12: 1108-1112, 2019.

24. Dedo HH and Yu KC: CO(2) laser treatment in 244 patients with respiratory papillomas. Laryngoscope 111: 1639-1644, 2001.

25. WHO: Update of recommendations on first- and second-line antiretroviral regimens. Geneva, Switzerland: World Health Organization; 2019. https://apps.who.int/iris/bitstream/ handle/10665/325892/WHO-CDS-HIV-19.15-eng.pdf?ua=1. Accessed February 12, 2021.

26. Longo D, Fauci A, Kasper D, Hauser S, Jameson J and Loscalzo J: Sexually transmitted and reproductive tract infections. In: Harrisons Manual of Medicine. 18th edition. McGraw Hill, New York, NY, pp873-874, 2012.

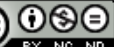

This work is licensed under a Creative Commons Attribution-NonCommercial-NoDerivatives 4.0 International (CC BY-NC-ND 4.0) License. 